Atlantic Oscillation (NAO) and the drought. In: Assessment of the Regional Impact of Droughts in Europe. Demuth, S. and Stahl, K.(eds). Final Report, ARIDE. Institute of Hydrology, Freiburg, pp. 106110

24. Jónsdóttir, J.F., Uvo, C.B. and Snorrason, Á. 2004 Multivariate Statistical Analysis of Iceland River Flow Series and Variability in Atmospheric Circulation. XXII Series and Varability in Ammosphere Circulation. XXIII 12 August 2004. NHP Report 48,9985-56-921-0.

25. Snorrason, Á. 1990. Hydrological variability and general circulation of the atmosphere. XVI Nordic Hydrological Conference, NHK-90, Kalmar, Sweden, 29 July-1 August 1990.

26. Wedgbrow, C., Wilby, R.L., Fox, H.R. and O'Hare, G 2002. Prospects for seasonal forecasting of summe drought and low river flow anomalies in England and Wales. Int. J. Climatol. 22, 219-236.

27. Wilby, R.L. 2001. Seasonal forecasting of UK river flows using preceding North Atlantic pressure patterns. J. Chartered Inst. Water Environ. Manage. 15, 56-63.

28. Wilby, R.L., Wedgbrow, C.S. and Fox, H.R. 2004 Seasonal predictability of the summer hydrometeorology of the River Thames, UK. J. Hydrol. 295, 1-16.

29. Kiely, G. 1999. Climate change in Ireland from precipitation and streamflow observations. Adv. Water precipitation and
Res. $23,141-151$

30. Kaczmarek, Z. 2002. The influence of the North Atlantic Oscillation on European river flow. In: The North Atlantic Oscillation and Its Role in Climate and Hydrology in Poland, 2002. Marsz, A.A. and Styszyńska, A. (eds.). Akademia Morska, Gdynia, pp. 163-172 (In Polish)

31. Kaczmarek, Z. 2003. The impact climate variability on flood risk in Poland. Risk Anal 23, 559-566.

32. Styszyńska, A. 2002. Relationships between the Warta River flow and winter NAO index in 1865-2000. In: The North Atlantic Oscillation and Its Role in Climate and Hydrology in Poland, 2002. Marsz, A.A. and
Styszyńska, A. (eds). Akademia Morska, Gdynia, pp. 173-180 (In Polish).

33. Limanowka, D., Nieckarz, Z and Pociask-Karteczka, J. 2002. The North Atlantic Oscillation impact on hydrological regime in Polish Carpathians. In. Interdisciplinary Approaches in Shall Catchment Hydrot

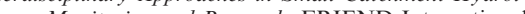
De Conference, Dema 2002, pp. 132-135.

34. Pociask-Karteczka, J., Limanówka, D. and Nieckarz, Z. 2002-2003. The North Atlantic Oscillation impact on hydrological regime of Carpathian rivers (19512000). Folia Geogr. Ser. Geogr. Phys. 33-34, 89-104 (In Polish with English summary).

35. Pociask-Karteczka, J., Nieckarz, Z. and Limanówka, P. 2003. Prediction of hydrological extremes by air D. 2003. Prediction of hydrological extremes by air 134-141.

36. Pfister, L., Humbert, J. and Hoffmann, L. 2002. Recent trends in rainfall-runoff characteristics in the Alzette River basin, Luxembourg. Climatic Change 45, 2, 323337.

37. Stefan, S., Ghioca, M. and Rmbu, N. 2004. Study of meteorological and hydrological drought in Southern Romania from observational data. Int. J. Climatol. 24, 871-881.

38. R'mbu, N., Boroneant, C., Buta, C. and Dima, M. 2002. Decadal variability of the Danube River flow in the lower basin and its relation with the North Atlantic Oscillation. Int. J. Climatol. 22, 1169-1179.

39. Rmbu, N., Dima, M., Lohman, G. and Stefan, S. 2004. Impact of the North Atlantic Oscillation and the El Niño-Southern Oscillation on Danube River flow variability. Geophys. Res. Lett. 31, 203-206.

40. Menduni, G., Baldi, M., Maracchi, G. and Meneguzzo, F. 2004. The Arno River seasonal discharge as an index of climate variability: trends and connections to the larger scale variability. Geophys. Res. Abstr. 6.05257.
41. Rodriguez-Puebla, C., Encinas, A.H., Nieto, S. and Garmendia, J. 1998. Spatial and temporal patterns of annual preicipitation variability over the Iberian Peninsula. Int. J. Climatol. 18, 299-316.

42. Trigo, R.M., Pozo-Vazques, D., Osborn, T.J., CastroDiez, Y. Gámiz-Fortis, G. and Esteban-Parra, M.J. 2004. North Atlantic Oscillation influence on precipitation, river flow, and water resources in the Iberian Peninsula. Int. J. Climatol. 24, 925-944.

43. Cullen, H.M. and deMenocal, P.B. 2000. North Atlantic influence on Tigris-Euphrates streamflow. Int. J. Climatol. 20, 853-863.

44. Heidi, M. Cullen, H.M., Kaplan, A., Arkin, P. and deMenocal, P.B. 2002. Impact of the North Atlantic Oscillation on Middle Eastern climate and streamflow. Climate Change 55, 315-338.

45. Rodwell, M.J., Rodwell, D.P. and Folland, C.K. 1999 Oceanic forcing of the wintertime North Atlantic Oscillation and European climate. Nature 398, 320-323.

46. Haarsma, R.J., Drijfhout, S.S., Opsteegh, J.H. and Selten, F.M. 2000. The impact of solar forcing on the variability in a coupled climate model. Space Sci. Rev. $13,1-6$.

Joanna Pociask-Karteczka

Institute of Geography and Spatial

Management

Jagellonian University

Department of Hydrology

Gronostajowa 7

Krakow, 30 387, Poland

j.pociask@geo.uj.edu.pl

\title{
Megacryometeors: Distribution on Earth and Current Research
}

The research of the historical record of ice falls brings together many cases that are apparently similar (1-3). Practically all clear-sky ice falls were not appropriately researched because they were routinely assigned, without verification, to aircraft icing processes, to wastewater from aircraft lavatories (blue ice), or to the leakage of aircraft water tanks. However, it is important to take into account, first, that documented historical references about these events go back to the first half of the 19th century, so many cases existed before the invention of airplanes (1-3), and second, that a detailed search of scientific databases (Web of Science, GeoRef) regarding well-known aircraft icing processes revealed a lack of precedents that corroborate that ice formation on any part of aircraft can reach dimensions of approximately $1 \mathrm{~m}$ and weights of up to several hundred kilograms.

A simplistic analysis of these events as a whole can thus lead to misunderstanding because different types of ice falls correspond to different formation scenarios in the earth's atmosphere, either natural in the strict sense of the term, or with a direct or indirect relation with human activities. Consequently, it is necessary to define differentiation criteria (e.g., texture, and structural and compositional characteristics of the ice) to distinguish among them (4). The term megacryometeor was recently coined (5) for the following reasons: to try to avoid terminological confusion; to emphasize the existence of such atmospheric phenomenon; and to describe large atmospheric ice conglomerations that, despite sharing many textural, hydrochemical, and isotopic features detected in large hailstones, are formed under unusual atmospheric conditions that clearly differ from those of the cumulonimbus cloud scenario (i.e., clear-sky conditions).

The fall of large ice blocks (weighing approximately $1 \mathrm{~kg}$ to hundreds of kilograms) from the clear sky is one of the most interesting (and controversial) issues in the atmospheric sciences (6). Meaden (6) used the term ice meteors to name them and proposed that their origin had to be different from that of large hailstones. Later, Corliss (1) used the term hydrometeors. Corliss also differentiated them from classic hailstones and suggested that they have an atmospheric origin, but different possible formation scenarios. Probably the largest and most impressive events of megacryometeors have occurred in China, Brazil, and Spain. In 1995, an ice block approximately $1 \mathrm{~m}$ in size fell in
Zhejiang, China (7). Some farmers witnessed three large chunks of ice crash with a whoosh into the paddies of Yaodou village; the largest chunk left a crater about a meter in diameter and a halfmeter deep. In Campinas and Itapira, Brazil, two huge megacryometeors of 50 and $200 \mathrm{~kg}$ fell in 1997; the atmospheric isotopic signature of both specimens was unequivocally confirmed (8). Finally, on 21 July 2004, a huge mass of ice weighing approximately $400 \mathrm{~kg}$ fell very close to a 15-year-old girl in Toledo, Spain.

Our study of the rate of these earthfall events indicates that mainly after 1950, the number of hits has spectacularly increased, and the hits occur over practically the whole planet (3). From 2001 to April 2006, a total of 46 ice-fall events have been witnessed and recorded. Verifiable effects include the megacryometeors' crashing through roofs or producing small impact craters (i.e., La Milana, Soria, Spain, Fig. 1; Surrey, UK; Oakland, California, USA). These impacts have occurred in Argentina, Australia, Canada, Colombia, India, Japan, Mexico, New Zealand, Portugal, Spain, Sweden, The Netherlands, the United Kingdom, and the United States. Fourteen ice falls occurred in 2005 alone; these occurred in Japan, The Netherlands, 


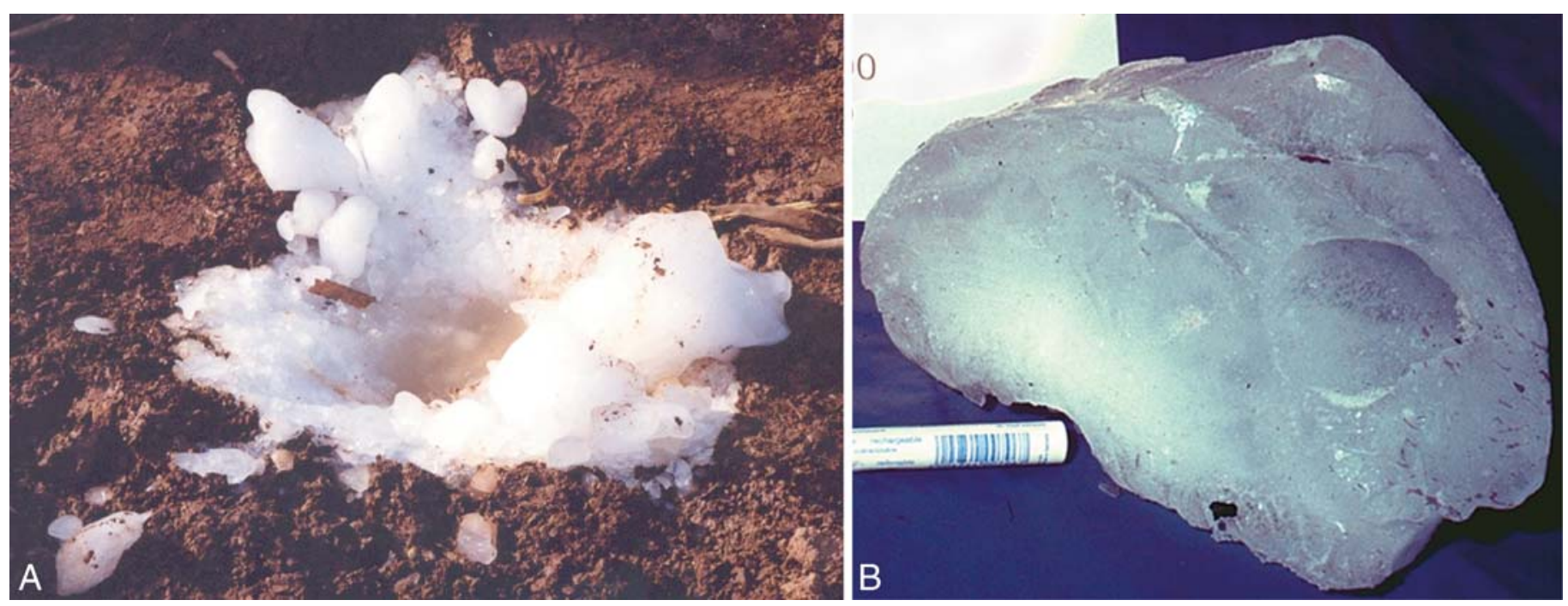

Figure 1. (A) Megacryometeor in situ that fell in La Milana, Soria (27 January 2002). It landed near a startled farmer who was riding his tractor. More than $16 \mathrm{~kg}$ of ice was recovered by the environmental police of the Guardia Civil (SEPRONA). The size of the small impact crater generated by the megacryometeor was $\approx 50 \mathrm{~cm}$. (B) One of the fragments of the megacryometeor that fell in San Feliz de Lena (Asturias) (26 January 2000 ) (artificial illumination to highlight its textural features).

the United States, the United Kingdom, and Spain, and the megacryometeors weighed from about $0.5 \mathrm{~kg}$ to more than $5 \mathrm{~kg}$. As of this writing, four documented ice falls have been recorded in 2006, one in India and three in the United States. The two last known events, in April 2006 in California (USA), produced a verifiable small impact crater on the ground in

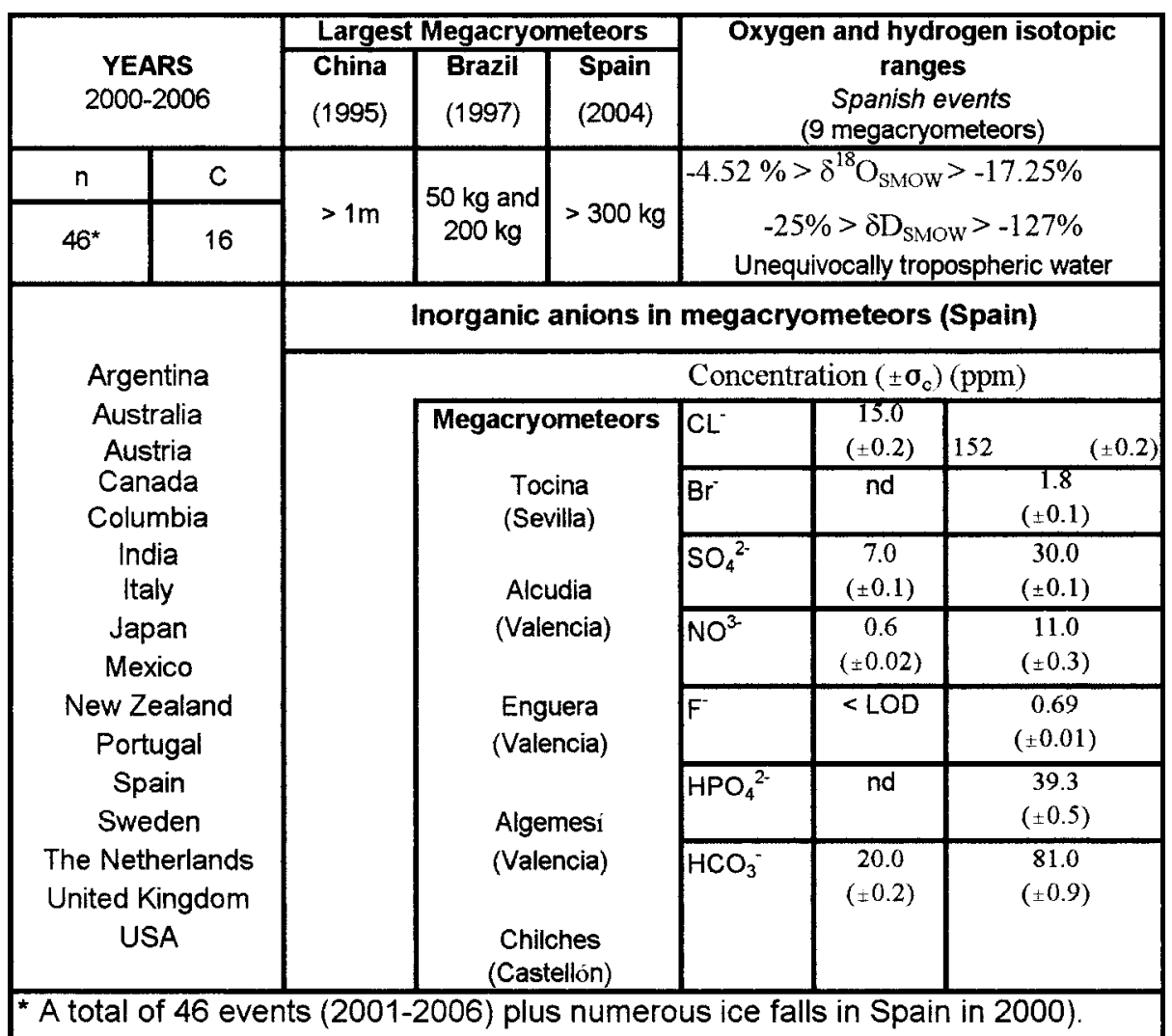

Figure 2. Selected significant information about megacryometeors. The hydrochemical and isotopic data corresponds to megacryometeors that fell in Spain. $[(2-4,11-14)$ and $h t t p: / / t i e r r a$. redirs.es/megacryometeors]. Abbreviations in the figures are C, number of countries; LOD, below the limit of detection; $\mathrm{n}$, number of ice fall events; nd, not detected; $(\sigma \mathrm{c})$, average concentration error; SMOW, Standard Mean Ocean Water.
Oakland and a hole in the roof of a gymnasium in Loma Linda $(9,10)$.

After 6 years of compilation and study of ice events occurring all around the world (10), together with the analysis of megacryometeors that fell in Spain during this period (Fig. 1), we are starting to understand the textural features and the hydrochemical and isotopic composition of megacryometeors (11-14) (Fig. 2) Megacryometeors' textures include zones of massive ice, large isolated cavities, millimeter-sized oriented air bubbles, and ice layering. Capillary electrophoresis analysis, combined with traditional wetchemical (molecular ultraviolet and visible-light spectrophotometry) of major anions $\left(\mathrm{Cl}^{-}, \mathrm{SO}_{4}{ }^{2-}, \mathrm{HPO}_{4}{ }^{2-}\right.$, and $\left.\mathrm{HCO}_{3}{ }^{-}\right)$ were performed by means of hydrostatic injection $(10 \mathrm{~cm}$ for $30 \mathrm{~s})$ at $25^{\circ} \mathrm{C}$. Trace anions $\left(\mathrm{F}^{-}, \mathrm{Br}^{-}\right.$, and $\left.\mathrm{NO}_{3}^{-}\right)$were quantified effectively by electrokinetic injection $(4 \mathrm{kV}, 10 \mathrm{~s})$ at $15^{\circ} \mathrm{C}$. The results showed variability in their chemical composition patterns (13). Very recent isotopic studies of megacryometeors confirm that $\delta^{18} \mathrm{O}$ and $\delta \mathrm{D}\left(\mathrm{V}_{\mathrm{SMOW}}\right)$ of all samples fall into the meteoric water line (15), unequivocally demonstrating that megacryometeors match well with typical tropospheric values (14). Also, theoretical calculations allow us to estimate that the vertical trajectory in effective growth of the megacryometeors was lower than $3.2 \mathrm{~km}$ (14).

At present, no model is able to satisfactorily explain what factors cause the ice nucleation and growth, or how these unusually large ice blocks can be actually formed and maintained in the atmosphere. Several hypotheses have been proposed that posit both terrestrial $(1,11-14,16)$ and cosmic (17) causes. The possibility that the source of the megacryometeor water could be nonterrestrial was considered, but this possibility was ruled out because as previously defined, the water signature $\left(-25 \%\right.$ o $>\delta \mathrm{D}_{\text {SMOW }}>-127 \%$ o (14) is clearly tropospheric (very different from that reported for comets $[+1028 \%$ > $\delta \mathrm{D}_{\text {SMow }}>+862 \%$ ]) (18). Crew (16) proposed that great masses of water (droplets and vapor) could be transported up into the atmosphere by tornados, then frozen and converted into ice chunks. Crew suggests the existence of some atmospheric mechanisms that would avoid 
dispersion and favor accretion of the ice. Our studies indicate that during the period in which the fall of megacryometeors to earth occurred in Spain (mainly during 10 17 January, 2000), anomalous atmospheric conditions were observed to exist $(12,14)$ : a sudden drop in the tropopause occurred over Spain. Atmospheric soundings from NOAA were collected for the days before and during the occurrence of the megacryometeors in Spain. The analysis of the soundings indicates that the tropopause sank from a level of $\approx 250 \mathrm{hPa}(\approx 10500$ $\mathrm{m}$ ) on the days before the events, to a lower level of $\approx 400 \mathrm{hPa}(\approx 7000 \mathrm{~m})$ on the days of the events. This process was not observed simultaneously at all stations and seems to have propagated from northwest to east and then to the south. Along with the amount of sinking, the other significant factor is the accompanying increase in humidity (near saturation but with no condensation) observed in all cases (except over Madrid). Ozone anomalies and wind shear were also found to coexist with the tropopause undulations.

Only by use of an interdisciplinary approach, including atmospheric and climatic studies, simulation, and analysis of physicochemical experiments of the ice will it be possible to learn the real cause of megacryometeors and the reasons for the apparent multiplication of these objects (19).

\section{References and Notes}

1. Corliss, W R 1983. Ice falls or hydrometeors In: Tornados, Dark Days, Anomalous Precipitation and Rernados, Dark Days, Anomalous Precipitation and ical Anomalies. The Sourcebook Project, P.O. Box 107, Glen Arm, MD 21057, pp. 40-44.

Glen Arm, MD 21057, pp. 40-44.
Martínez-Frías, J. and López-Vera, F. 2000. Los bloques de hielo que caen del cielo. Antecedentes y fenomenología reciente. Rev. Educa. Cienc. Tierra. 8 , 130-135 135 (In Spanish)

Martínez-Frías, J. and López-Vera, F. 2002. Grandes bloques o meteoros de hielo. In: Riesgos Naturales. Ayala-Carcedo, F.J. and Olcina Santos, J. (eds). Ariel Ciencia, Editorial Ariel, S. A., 1141-1148 (In Spanish). Martinez-Frias, J and Rodriguez-Losada, J.A 2006. Atmosperic merom Atmospheric megacryoreteor events versus small Atmospheric megacryon of a potential noct Impacts and Hickman, H. (eds). ICSU. Springer. (In press).

Martinez-Frias, J. and Travis, D. 2002. Megacryometeors: fall of atmospheric ice blocks from ancient to modern times. In: Environmental Catastrophes and Recovery in the Holocene. Leroy, S. and Stewart, I.S.(eds). Brunel University, West London, UK, pp. 54-55.

. Meaden, G.T. 1977. The giant ice meteor mystery. $J$. Meteor. 2, 137-141

Parker, J. 1995. (http://www2.jpl.nasa.gov/s19/news56. html)

8. Pinto, H. 1997. Segundo relatório sobre o fenômeno da queda de blocos de gelo provenientes da atmosfera nas
regiees de Campinas e de Itapira, NO Estado de São Paulo, Brasil. (http://www.cpa.unicamp.br/gelo/gelo. Paulo,
html)

9. (http://tierra.rediris.es/megacryometeors)

0. (http://www.phschool.com/science/planetdiary/ archive06/atmo 1042206.html

11. Martínez-Frías, J., López-Vera, F., García, N., Delgado, A., García, R. and Montero, P. 2000. Hailstones fall from clear Spanish skies. Geotimes (June): 6-7.

2. Martínez-Frías, J., Millán, M., García, N., López-Vera, F., Delgado, A., García, R., Rodríguez-Losada, J.A. Reyes, E., Martín Rubí, J.A. and Gómez-Coedo, A. 2001. Compositional heterogeneity of hailstones: atmospheric conditions and possible environmental implications. Ambio 30, 450-453.

Santoyo, E., García, R., Martínez-Frías, J., LópezVera, F. and Verma, S.P. 2002. Capillary electropho- retic analysis of inorganic anions in atmospheric hailstone samples. J. Chromatogr. A 956, 279-286.

14. Martinez-Frias, J., Delgado, A., Millan, M., Reyes, E. Rull, F. Travis, D., García, R., López-Vera, F. et al. 2005. Oxygen a 2005. Oxygen and hydrogen isotopic signatures of large atmospheric ice conglomerations. J. Atm. Chem. 52, $185-202$

15. Craig, H. 1961. Isotopic variations in meteoric waters. Science 133, 1702-1703.

16. Crew, E.W. 1977. Fall of a large ice lump after a violent stroke of lighting. J. Meteor. 2, 142-148.

17. Foot, R. and Mitra, S. 2002. Ordinary atom-mirror atom bound states: a new window on the mirror world. Phys. Rev. D 66, 061301.

18. Deloule, E., Robert, F. and Doukhan, J.C. 1998 Interstellar hydroxyl in meteoritic chondrules: implications for the origin of water in the inner solar system. Geochim. Cosmochim. Acta 62, 3367-3378.

19. Thanks to Dr. David Hochberg for his revision and correction of the English-language version of this article. Also thanks to CSIC and ICSU for their scientific support.

\section{Jesus Martinez-Frias}

Planetary Geology Laboratory

Centro de Astrobiologia, Ctra de Ajalvir, km. 428850 Torrejón de Ardoz

Madrid, Spain

martinezfrias@mncn.csic.es

\section{Antonio Delgado Huertas}

Department of Earth Sciences and

Environmental Chemistry Estación

Experimental del Zaidín, CSIC Prof.

Albareda 118008 Granada, Spain

antodel@eez.csic.es

\section{Ecological Economic Problems and Development Patterns of the Arid Inland River Basin in Northwest China}

The inland river basin in arid Northwest China is located in the center of the Eurasian continent, north of $35^{\circ} \mathrm{N}$ and west of $106^{\circ} \mathrm{E}$, occupying $24.5 \%$ of China's total land area, and it is one of the most arid regions in the world (1). This region is characterized by alternating bands of relatively humid mountains and arid plains. Several rivers, such as the Heihe, Shiyang, Shule, and Tarim, originate in the mountainous regions, nourish some oases in the middle reaches, and then flow to small lakes or disappear in the large arid desert plain. Alternating mountains, oases, and desert is the typical landscape pattern of the arid inland river basin in Northwest China. Although there is more agricultural and animal husbandry production in these basins than in other arid regions, water resources are the most significant factor restricting basin devel- opment (2). We take the Heihe River Basin as a case to focus on some critical ecological economic problems that have recently arisen in the inland river basin, and we put forward a sustainable development pattern according to the system coupling theory.

\section{STUDY AREA}

The Heihe River Basin (HRB), the second largest inland river basin in arid Northwest China, is located between $97^{\circ} 42^{\prime}-$ $102^{\circ} \mathrm{E}$ and $37^{\circ} 41^{\prime}-42^{\circ} 42^{\prime} \mathrm{N}$. It covers an area of approximately $128000 \mathrm{~km}^{2}$. The main stream of the Heihe River, with a length of $821 \mathrm{~km}$, originates in the Qilian Mountians, flows through the Hexi corridor of Gansu Province, and enters into two terminal lakes (Fig. 1). The landscape and human production are very different in the HRB. In the upper reaches of the HRB, mountain grassland and forest are the main landscape types, and desert grassland is the main landscape type in its lower reaches. Therefore, the main human production in the upper and lower reaches of HRB is animal husbandry based on mountain grassland and desert grassland. In the middle reaches of the HRB, irrigation oases are distributed along the sides of the Heihe River.This is a productive zone of economic development for the entire HRB: $88.47 \%$ of the HRB population lives here, and $87.93 \%$ of the HRB GDP are focused here. It is one of the major grain-producing regions in China. However, because water utilization intensity is continuously increasing in the oases located in the middle reaches of the $\mathrm{HRB}$, the discharge of water into the lower reaches of the river has decreased signifi- 